UDC 631.427.2

Review paper

doi: 10.5937/AASer1948191M

Acta Agriculturae Serbica, Vol. XXIV, 48(2019); 191-207

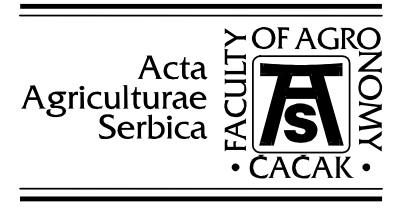

\title{
Microorganisms of soil ecosystems and their health
}

\author{
Semenov Aleksander Mihailovič ${ }^{1}$, Đukić Dragutin $^{2}$, Mandić Leka \\ 1 Faculty of Biology, Department of Microbiology, M. V. Lomonosov Moscow \\ State University, Leninskie gori, 1/12,119234, Moscow, Russia Federation. \\ 2 Faculty of Agronomy, Department of Biology, Microbiological Biotechnology, \\ University of Kragujevac, 32000, Cara Dušana 34, Čačak, Serbia. \\ *Corresponding author: amsemenov@list.ru
}

\begin{abstract}
The current (at the end of the first quarter of the 21 century) ideas about the microbial community (MC), structure and concepts reflecting and summarizing progress in the knowledge of the MC are considered. The ideas about the microbial community are discussed from the point of view of modern knowledge of the role and functions of microbial communities in the emergence and maintenance of a product that is traditionally called a rather short and succinct term - soil, but which, in essence, is a product of interactions of various biological communities and substances which is infinitely multi-valued and differently conceptual, and is an ecosystem, a soil ecosystem (SE). It justifies the need to develop a new concept for the knowledge of this product - soil health ( $\mathrm{SH}$ ), as an integration of modern knowledge of MCs and their functions. Methods for determining the parameters of soil health are briefly described.
\end{abstract}

Keywords: microbial community, concepts, soil, soil ecosystem, soil health.

\section{Introduction}

In the first quarter of the 21st century, population microbiology, microbial ecology and soil sciences have amassed experimental and theoretical experience, which calls for careful consideration in search of obvious and hidden mutual relationships to further the knowledge of nature. This particularly refers to the knowledge of the structure of the microbial community (MC). The general progress in the knowledge of MCs and their functions, along with the consideration of facts and consequences with respect to the ability of microorganisms in MCs, has stimulated the acquisition of knowledge about the role of the $\mathrm{MC}$ and its abilities in the most 
complex terrestrial ecosystem - the soil ecosystem (SE). This has resulted in a new category of the SE - soil health. To gain further knowledge of the SE, a simple and easy-to-use fundamental approach is exactly what is needed. All of this requires researchers and users to employ dynamism, judiciousness and temporally integrative actions.

The objective of this communication is to generalize knowledge of the structure of the microbial community and the influence of this knowledge on other fields of microbial ecology, such as the microbial community of the soil ecosystem, with respect to the emergence of the new category of the soil ecosystem (soil) - soil health.

\section{The origin of the concept of the microbial community (MC)}

Research into the properties, abilities and specific nature of microorganisms is taking place only at the microbial population level i.e. using a multitude of identical single-celled organisms that are invisible to the naked eye, with only the ultrastructure of an individual cell recognizable on the selected organism. In nature, microorganisms live in the form of a multitude of different populations. It is quite logical to expect influences among populations, as well as their interactions, manifested through different processes, either noticeable or unnoticeable ones. These interactions have already been termed as competition, antagonism, neutralism, cooperation, synergism, syntrophy etc. It is absolutely logical to expect populations to undergo changes in terms of quantity and/or quality, over time and space. To express this multitude of different populations existing in place and time, the term "community" is used. As a term, "community" also encompasses "the multitude of the multitude" of communities. Obviously, it is precisely this meaning that has paved the way for the establishment of this term in the science of biology i.e. a multitude of different types of single-celled organisms/populations that are invisible to the naked eye, which is designated as a microbial community.

The notion about the microbial community (MC) is the key to the ecology of microorganisms. The structural elements of the $\mathrm{MC}$ and the manner of their representation determine the choice of research strategies and tactics, and the application of the knowledge acquired. The term "microbial community" has synonyms that strive to explain the content of the essence. These include the terms: association, consortium, microbiota and, even, microbial complex (Звягинцев, 1987; Звягинцев et al., 1999; Добровольская, 2002; Котелевцев, 2019; Đukić et al., 2019). Also, there are, undoubtedly, other terms, proposed in earlier history, which were coined to express and reflect the multitude of different populations existing in the living world. For instance, the term "consortium" deals with the concept of socium, which denotes a social sphere of the human community. To separate the social community from living communities - living matter, the term "cenosis" was devised and further specialized as phytocenosis, microbial cenosis, biocenosis, biogeocenosis etc. 


\subsection{Characterization of the MC structure}

The term "community", which is generally accepted by the scientific community, will be used from this point onwards. The development of notions about the microbial community and the types of structure of a community and communities - trophic, functional, spatial, taxonomic etc. - has gone hand in hand with achievements with regard to the methods used to investigate and gain knowledge of, first of all, the trophic biological diversity of microorganisms. To acquire knowledge of the $\mathrm{MC}$, a whole range of biological and physicochemical methods are actually used. Since this review centers upon the microbial community, i.e. bacterial and micromycetal ones, let us turn our attention to the following definition of the microbial community. "A microbial community should be considered as a whole made up of taxonomically different but functionally interrelated populations of microorganisms existing for some time in a certain place." The components of the MC can be either strongly interrelated, even physically, making the MC highly specialized, or poorly interrelated, when the MC has a low level of specialization (Semenov, 1991; Семенов, 2005, 2010, 2011). Tо what end is it necessary to have an idea about the MC structure, as well as about each particular MC and in each ecotype of interest for both researchers and practioners (although this is ultimately unreachable)? The more objective and accurate the concept of the MC structure, the greater its interpretative and prognostic properties (functions), and the greater the probability of finding an adequate solution in ecological and industrial biotechnology. It is important to emphasize that the abovementioned definition of the MC entails potential changes in the MC over time and space, suggesting its dynamic nature. Along with dynamism, it is important to know its functional compostition, the diversity of its components and their numbers in the MC. The taxonomic composition is of third-rate importance, as it is a dominant process at the microlevel. This is confirmed by the very important set of methods used in microbial ecology - biogeochemical methods. In these methods, microorganisms (communities!) performing certain processes are judged by the products of these processes using physicochemical methods, which are visible at the macro level. For example, the strong odor of hydrogen sulfide indicates that intensive sulphite reduction is taking place.

\subsection{The evolution of knowledge about the MC structure, and trophic groupings within the $\mathrm{MC}$}

At the very end of the 20th century and in the first quarter of the 21 st century, in the context of, basically, the absolute domination of molecular biological methods for microbial identification, gaining knowledge about the key i.e. trophic structure of the microbial communities existing in geochemically "moderate" ecological niches received decreased attention. Neverteheless, interest in exploring trophic interactions in anaerobic MCs, particularly in niches of anthropogenic origin was maintained (Заварзин, Бонч-Осмоловская, 1981; Ножевникова, 1987, 1991; Заварзин, 1990а; 
Zumstein et al., 2000; Hofman-Bang et al., 2003), as well as in natural niches - under extreme conditions (Заварзин et al., 1993, 1999; Заварзин, 2004). In addition, today, instead of focusing on physiological and biochemical aspects of the MC, research is oriented towards taxonomic aspects and the molecular biological composition of $\mathrm{MC}$ components (Kirk et al., 2004; Hug, 2018). However, understanding and management of MCs require knowledge about the number, functions and activities of organisms, and not just about electrophoretic DNA bands with further important conclusions about MC potentials and scarce current results. To gain an in-depth knowledge of the MC and ensure its successful utilization, it is vital to know the physiological composition of the $\mathrm{MC}$ first, and then, finally, its taxonomic i.e. molecular biological composition (Hug, 2018).

The knowledge of the MC is formally divided into several periods. Inter alia: The quantification i.e. perception of the large number of microorganisms. Gaining knowledge about the many faces of the functional ability, evolutionary agility, as expressed by Beijerinck's idea that "everything is everywhere, but the environment selects". This was supported by progress in physicochemical research methods (microscopy, chromatography, electrochemistry, electrophoresis etc.). Gaining knowledge of the fact that microorganisms can be found not only in environments rich in organic matter, primarily in natural environments, but also in ecotopes and econiches that are very poor in organic matter, and even in inorganic environments.

To facilitate the understanding and perception of the infinite depth of the MC structure, "models" of the MC structure are used. Without delving into the chronology of ideas about the microbial community structure, we shall mention only the historically most important examples of ideas and notions about the microbial community structure through trophic groupings.

Every organism has its limits of existence, and its properties and peculiar features are maintained within specific physiological characteristics and constants. As the terms "oligotrophic bacteria' (OB) and "copiotrophic bacteria" (CB) will be used from this point onwards, it is appropriate to remind about the definitions of these groups (Semenov, 1991). OB are organisms that are evolutionary adapted to live in environments characterized by low organic substrate concentrations and low energy flows. They have highly effective systems for the absorption (uptake) of organic and inorganic nutrients that occur at nano- and even picomolar concentrations in these niches. At the same, oligotrophs, within the range characteristic of each particular organism, may develop in environments, either natural or experimental ones, which are quite rich in organic nutrients. However, only extremely poor, yet qualitatively complete, environments are suitable for the isolation and characterization of oligotrophs because it is only under such conditions that the competitive advantage of their oligotrophy can be exhibited (Семенов, 2005; Semenov, 1991). Copiotrophic bacteria have opposite properties, as defined by Poindexter (1981) (cit. after Semenov, 1991). 
Table 1. Examples of trophic groupings within the microbial community structure (Семенов, 2005)

\begin{tabular}{|l|l|l|}
\hline Groups & Distinctive features & $\begin{array}{l}\text { Author } \\
\text { conсерt }\end{array}$ \\
\hline $\begin{array}{l}\text { Two groups: autotrophs } \\
\text { and zymogens }\end{array}$ & Growth rate and substrate structure & Виноградскии, 1952 \\
\hline $\begin{array}{l}\text { 14 groups, including } \\
\text { hydrolytic and dispersed } \\
\text { microorganisms } \\
\text { (dissipotrophs) }\end{array}$ & $\begin{array}{l}\text { Growth rate, exohydrolase producing } \\
\text { ability, substrate type and substrate } \\
\text { concentration }\end{array}$ & $\begin{array}{l}\text { Заварзин, 1970; 1976; } \\
1995 .\end{array}$ \\
\hline $\begin{array}{l}\text { Heterotrophs are divided } \\
\text { into copiotrophs and } \\
\text { oligotrophs }\end{array}$ & $\begin{array}{l}\text { Substrate concentration, substrate type } \\
\text { and growth kinetics }\end{array}$ & Poindexter, 1981. \\
\hline $\begin{array}{l}\text { 4 groups: autotrophs, } \\
\text { zymogens, oligotrophs } \\
\text { and lithotrophs }\end{array}$ & $\begin{array}{l}\text { Growth rate, substrate type and substrate } \\
\text { concentration }\end{array}$ & Мишустин, 1982. \\
\hline r-K continuum & Growth rate and substrate concentration & Gerson, Сhet, 1981. \\
\hline $\begin{array}{l}3 \text { groups: oligotrophs, } \\
\text { stenoheterotrophs and } \\
\text { euryheterotrophs }\end{array}$ & Substrate concentration & Ногоwitz et al., 1983. \\
\hline $\begin{array}{l}3 \text { groups: copiotrophs, } \\
\text { hydrolytics and } \\
\text { oligotrophs }\end{array}$ & $\begin{array}{l}\text { Substrate type, substrate concentration, } \\
\text { hydrolase producing ability }\end{array}$ & Гузев, Иванов, 1986 \\
\hline $\begin{array}{l}\text { "Autochthonous" } \\
\text { microorganisms are } \\
\text { divided into 3 groups: } \\
\text { hydrolytics, "patients" } \\
\text { and oligotrophs }\end{array}$ & $\begin{array}{l}\text { Exoenzyme producing ability, substrate } \\
\text { structure and growth rate }\end{array}$ & Gordienkо, 1990. \\
\hline
\end{tabular}

A comparative analysis of some kinetic characteristics of $\mathrm{CB}$ and $\mathrm{OB}$ growth, such as similarity between microbial transport systems in terms of substrate (Ks - for growth kinetics and $\mathrm{Km}$ - for substrate transport kinetics), maintenance energy - $\mathrm{m}$ and marked presence or absence of "narrow (regulatory) sites" in microbial metabolism, enables the trophic (physiological) grouping of microorganisms. The "narrow site", the limiting segment in the metabolism of oligotrophs, is obviously filled with the respiration chain (Semenov, 1991).

The exploitation of the kinetic growth characteristics for the distinction between $\mathrm{OB}$ and $\mathrm{CB}$, with the concentration and types of substrates considered, has led to the conclusion that the total diversity of heterotrophic microorganisms can be presented in the form of a continuum, in which microorganisms having extremely high characteristics are grouped on one end, and those with low characteristics on the other.

As established long ago, the dominant majority of microorganisms have moderate and mutually close characteristics (Стейниер et al., 1979; Заварзин, 1990б; Hug, 2018). The division of the entirety of microbial diversity into copiotrophs and oligotrophs does not 
reflect the entire essence of the world of microorganisms, and even the consideration of the notion of the $\mathrm{r}-\mathrm{K}$ continuum does not solve the problem. The solution to the problem regarding the rough categorical nature of the structural division is proposed by the $\mathrm{MC}$ scheme, which is based on notions about the norm of reaction. As explained by general genetics, the norm of reaction reflects the morphophysiological variation of an organism, while the genotype remains unchanged. In the proposed scheme, microorganisms are divided into three unequal groups, and the $\mathrm{MC}$ is presented in vector form, using a symmetrical/assymetrical structure, which reflects the continuum of forms, populations and communities (Figure 1) (Semenov, 1991). The two extreme groups are represented by organisms having narrow reaction norms relative to the concentration and type of substrates used, on the one hand, and limits of variation in physiological characteristics $\left(\mathrm{K}_{\mathrm{m}}, \mathrm{m}\right.$ and $\mathrm{V}_{\mathrm{dis}}$ ), on the other. These groups, according to their properties, belong to real copiotrophs and real oligotrophs. The third group with a broad norm of reaction includes the majority of known heterotrophic microorganisms, and is positioned between the groups with a narrow norm of reaction (Hug, 2018). Since the MC exists in both time and space, it is more appropriate to represent its structure as a three-dimensional scheme, for the calculation of spatial/temporal characteristics and trophic groupings (Figure 2).

The present dynamic concept does not reject previous notions (Table 1); it includes or develops them. The proposed concept of the trophic structure of the MC contains explanatory and prognostic characteristics.

The concept explains, for example, why microbial growth is lower on very rich or very poor organic media than on "diluted" ones. This is because "diluted" media serve not only for the growth of microorganisms having broad reaction norms but also for the growth of part of microorganisms with narrow reaction norms. The concept explains why bacteria isolated as oligotrophs are often taxonomically classified as typically copiotrophic taxa, for example Pseudomonas, Spirillum and even Escherichia and Bacillus (Fry, 1990). It is these very genera that include bacteria with broad norms of reaction. The proposed scheme of the MC structure suggests that the number of real oligotrophs and copiotrophs is not high (minority), and that the bulk of microorganisms is represented by organisms with moderate characteristics. Industrially important microorganisms should be sought primarily among microorganisms with broad reaction norms, while those with narrow reaction norms will prevail in ecological niches having extreme characteristics.

The proposed MC model has been elaborated using the properties and characteristics of heterotrophic microorganisms (chemo-organo-heterotrophs). There is the question of the position of autotrophic microorganisms in this $\mathrm{MC}$ model, whose existence is indifferent to the concentration of organic carbon, and the concentration of this source of carbon $\left(\mathrm{CO}_{2}\right)$, which they need, is not under their control. However, the position for the existence of this MC component can be quite realistically set in the proposed symmetrical/assymetrical structure or even in the whole autotrophic (chemo-litho-autotrophic) community. Noteworthy, autotrophic sites, according to the content of Corg, are oligotrophic or even extremely oligotrophic habitats; part of autotrophs are capable of mixotrophy, and competition and selection among autotrophs are also realistic, as they are among heterotrophs. 


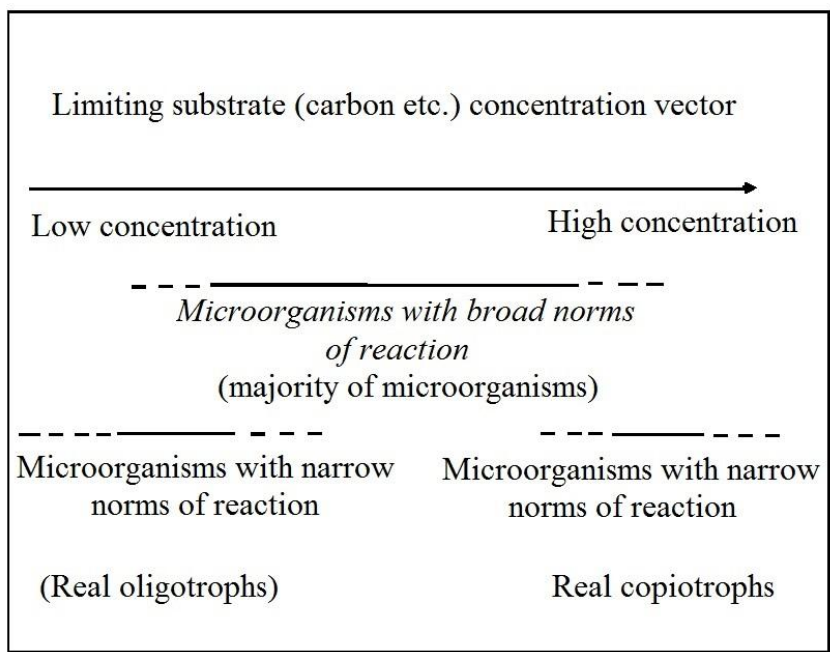

Figure 1. Microbial groupings in the microbial community scheme.

Symmetrical/assymetrical structure with different, partially overlapping trophic groups

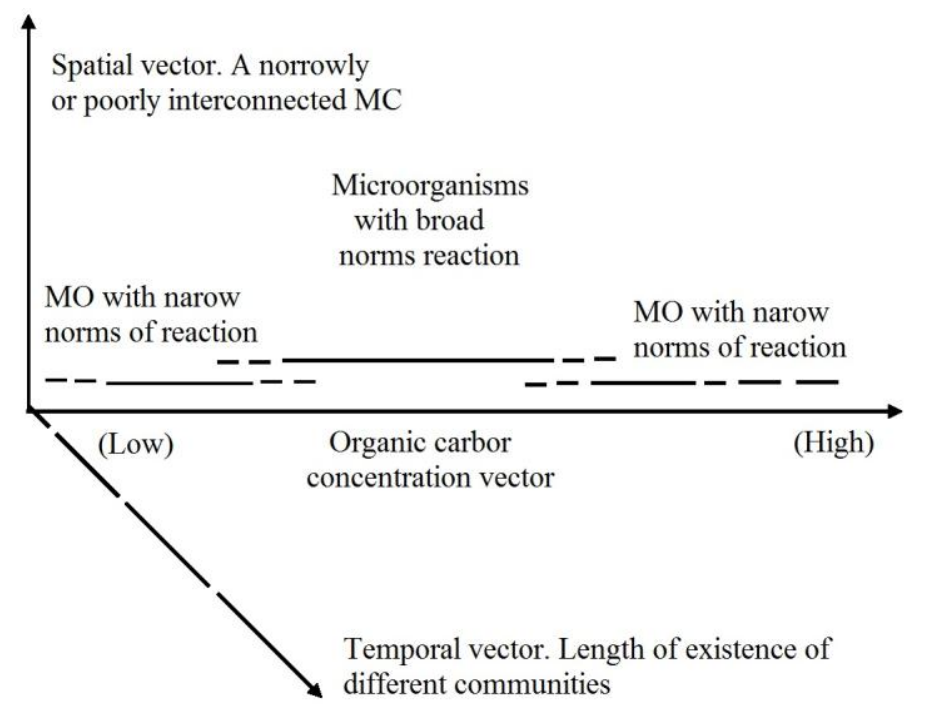

Figure 2. A schematic three-dimensional representation of the microbial community structure

\subsection{General postulates in the knowledge of the MC; laws and concepts related to the MC}

To date, there have been a considerable number of generalized postulates regarding the knowledge of the functions and properties of the MC, which can be designated as 
laws, according to their importance, but they are currently commonly termed "concepts". Concepts in biology, microbiology and microbial ecology have the same role and importance as those attributed to legal laws in a social community. The more accurate and concrete the laws (concepts) and the more accurately they are adhered to by users, the greater the user insurance against failure of biotechnological ecology. The more accurate (precise) the proposed MC structure, the deeper its predictive (prognostic) traits (functions), which is indeed the fundamental goal of gaining knowledge of a community.

Let us discuss the well-known and recognized laws and concepts, without mentioning the time of their first occurrence, and only those related to the MC, similarly to the species concept, for example, which does not belong only to microbial ecology. It is important to point out, finally, that the first concept to emerge is the one dealt with in this review paper - the concept of the microbial community (Заварзин, 1970; Semenov, 1991).

The best-known and most important biological laws and concepts are: (1) the exponential growth ability of all populations (and the community); (2) self-limitations (limitation or inhibition) of their growth; (3) fluctuating life dynamics of populations (due to limitation or inhibition). These three laws (concepts) are objective for all living organisms, and therefore for microorganisms as well. Турчин (2002) realistically compared their importance to the first three physical laws of dynamics. It is obvious that the three laws should be enhanced by the observation about limitations to adaptation due to the reaction range of the organism relative to environmental conditions.

The recognition of another concept is underway: the concept about the MC as not only a basic functional unit of the ecosystem, but also as its evolutionary unit (Заварзин, 1990a), with microbial evolutionary development taking place both inside the community and through the community. The concept of microbial evolution both inside the community and through the community, along with the concept of symbiosis and succession, directs theoreticians and practitioners to a systemic approach to achieving results. Using stable microbial communities is the pathway to the management of natural microbiological processes.

The concept of the importance of processes in an ecosystem and their dependence on the number and activities of microorganisms involved in them (the only process of importance and prominence is the one performed by a multitude of active microorganisms - Заварзин, 1989) has a deeper sense. This concept is consistent with the philosophical law of the transition of quantitative processes into qualitative ones. Discovering several cells of a saprotrophic microorganism in a habitat is not indicative of the importance of the process, which is potentially important if performed by a multitude of such microorganisms. The phenomenon actively exploited in the literature under the name "quorum sensing" is only a manifestation of the already formulated concept.

Comprehensiveness is provided by the concept of the food chain and the food pyramid. This concept is complemented by the concept of interactions between large and small organisms, according to which large organisms exploit and even directly 
consume smaller ones, while the smallest ones often parasite on large ones. This concept is, obviously, applicable not only in microbial ecology but also in general ecology and all branches of biology. The concept is further expanded by the concept of symbiosis i.e. coexistence of organisms.

The law closely connected with the previous ones as their continuation is the law of succession. According to this law, if environmental disturbance or change is severe, coexistence is disturbed (degraded), leading to the succession of organisms (species). This is often the case in treatment plants or other unit operations based on the exploitation of natural and, to a greater degree, artificially fabricated MCs.

Apart from these general ecology concepts, there is a well-known range of specific, pedomicrobial concepts. It seems that Zvjagincev was the first to deal with some of them (Звягинцев, 1987; Звягинцев et al., 1999). The concept of the microbial pool and its surplus in the soil compared to the availability of nutrient resources. According to the concept, the vital body of microbial biota exceeds the amount of available nutrients, due to which microorganisms are largely devoid of food and starving, and are hence in the physiological survival state (dormant state, anabiotic state and even viable noncultivable). This concept is of particular importance when introducing microorganisms into a natural ecosystem to achieve pragmatic goals.

The concept of functional interchangeability, functional parallelism among microorganisms or functional doubling. As generally known, one and the same function, for example, cellulose degradation, can be performed by bacteria, actinomycetes and fungi, i.e. procaryotes and eucaryotes. The parallelism of functions and doubling of functions are diverse, and play a role not only in global processes such as cellulolysis, fermentation or oxidation, but also in local ones. The suppression and, to a greater degree, elimination of a functional group cause an increase in the numbers and activities of the functional double, which is often completely undesirable.

The concept of microzonality of the soil as the living environment for microorganisms, along with the concept of the surplus of the microbial pool in the soil, reminds that, for example, the introducee will be vital if present in microzones, on the one hand, and if the substrate is available in the microzones, on the other.

The concept of the $\mathrm{r}-\mathrm{K}$ continuum in microbial ecology expresses the continuity and discreteness of properties and diversity of organisms. The concept of oligotrophy explains the importance and meaning of the origin and survival of oligotrophic ecosystems as the mechanism for the creation and maintenance of healthy ecosystems (and, of course, the soil).

The concept of the regulation of activities of a natural MC shows that changes in the activities of the MC in nature result not so much from changes in the activities of the dominant components of the MC as from changes in the community composition through succession (Семенов, 2005).

The concept of disturbing influences and fluctuating development of microbial populations (MPs) and the MC is the continuation and development of the (third) population law of general ecology. However, the cause of the fluctuating dynamics in general ecology is, traditionally, the relationship between the predator and the prey, 
while in microbial ecology - it is the interaction between the substrate and the consumer, which causes the succession of growth stages and death of MPs and the MC. The role of predation ("eating") in the fluctuating development of MPs and the MC is tertiary. The fluctuating dynamics of MPs and the MC is driven by internal and external disturbing influences that are continuously occurring in nature. The fluctuating dynamics of MPs and the MC takes place in both time and space. The concept of disturbing influences and fluctuating dynamics of the $\mathrm{MC}$ is the basis for the elaboration of methods for the determination of health parameters for the soil, compost and other solid substrates (Семенов, 2005; Van Bruggen, Semenov et al., 2006; Семенов, Ван Бругген et al., 2009, 2011б).

The concept of disturbing influences and fluctuating development of MPs and the $\mathrm{MC}$ is connected with the concept of the cycle of microorganisms or the microbial cycle (Семенов, 2005; Semenov et al., 2010). The cycle of microorganisms or microbial cycle refers to continuous shifts (transitions) of specific cells, MPs and the MC through major natural environments, such as the soil or water, plants, animals, excrement and/or excreta from animals and plants and, again, the soil or water. The microbial cycle concept complements the notions about the MC structure, and reflects MC adaptability, succession, ability to adapt, selection of the best adapted organisms, and links the disturbing influences and the fluctuating development of MPs and the MC. The microbial cycle, as a shift of MPs and the MC along the food chain coupled with the cycle and "network" formation, is a natural source and a permanently acting mechanism of the disturbing influences on the MC. Practically, the concept of the microbial cycle means stating reasons for the need to examine traditional epidemiological notions about reservoirs, sources, habitats and vectors i.e. transmitters of infectious agents.

In this way, the dynamic, vector-like, symmetrical/asymmetrical structure of the MC containing different trophic groups, which reflects the continuum of forms, populations and communities with the established set of laws and concepts, creates an objective basis for the understanding and exploitation of MC function mechanisms, both in natural and anthropogenic ecosystems. Such knowledge of the MC ensures that it is reasonable not only to expect results from planned processes but also to identify potential risks of unpredicted (unprognosed) phenomena.

\section{Soil ecosystem}

Soil is studied by different sciences, which often use the same or similar methods to achieve different goals and tasks. Hence the different definitions of "soil" as a traditional term. Defining the term "soil" is still dominated by the evolutionary/phylogenetic approach which mostly uses physicochemical conceptions and global standards. Modern knowledge requires that soil be studied as a multi-valued ecosystem coupled with its biological diversity and globally important and already noticeable anthropogenic influences (Semenov, Semenova, 2018). It should be emphasized that there is still no clear and meticulous definition of soil. 


\subsection{The origin and formation of soil}

In scientific considerations of the pedogenetic process, the descriptions provided by Dokuchaev, Kostichev, Vernadsky, Aristovska, Kovda, Dobrovolsky and other scientists are usually referred to. The importance of Earth's parent rock erosion is confirmed, and the settlement of the planet's crystalline rock surfaces by chemolithotrophic (anaerobic?) bacteria is mentioned. "They speak about the microorganisms that affected sedimentary rocks through chemical and physical degradation and transformation into the organomineral substrate suitable for settlement by higher plants and the accompanying fauna, leading to the formation of original primitive soils (Добровольский et al., 2011). Such reconstructions cannot contain important details of the process, those which are still without answers. Therefore, these reconstructions remained in the sphere of phantasy. For example, it is estimated that life on Planet Earth dates back 3.8 billion years ago. Life - it is a selfdeveloping cyclic system ("the eternal originator"), entailing death as well. Accordingly, one can also speak of the accumulation of dead organic matter. At the very least, part of this matter, in a relatively short period of time, must transfer the strength of autohydrolysis and external influences into the matter which makes up, at least, part of that same organic matter in contemporary soils. However, it should be emphasized that there is still no clear and generally accepted definition of soil.

The official issue of ГOCT 27593-88 Soils. Terms and definitions (2008) (URL http://docs.entd.ru/document/1200007341) provides the following definition of soil: soil is "an original, natural/historic organomineral body that originated on earth's surface as the result of long-term effects of biotic, abiotic and anthropogenic factors, which consists of solid mineral and organic particles, water and air, and which has specific genetic and morphological properties, which create suitable conditions for plant growth and development". Even a superficial analysis of this definition shows the presence of substantial contradictions. Of course, soil as a system, an ecosystem, had originated billions of years before anthropogenic factors occurred i.e. man (Homo sapiens?) first appeared two million years ago, at the most. The definition uses the term "body", which creates conditions for plant growth and development. This indicates that the "body" was the first to emerge, the body which created conditions for plant growth and development. Who created the organic part of this "body"? Certainly, the reconstruction of events regarding the origin of soil, dating back to billion years ago, is bound to produce many questions.

The previous chapter discusses the microbial community in terms of the basic integrating characteristic within the MC structure - trophics. Trophics is nutrition, consumption. Bacteria (procaryotes) and fungi (eucaryotes) are organotrophs. It is only starting from some single-celled protozoa that holozoic nutrition appears. For osmotrophic nutrition, solid or liquid polymerous matter must undergo hydrolysis (destruction). Microorganisms with hydrolytic abilities (hydrolytic enzymes, exoenzymes) have come to be called hydrolytics. All microorganisms, bacteria in particular, do not have hydrolytic properties; actually, the minority of them exhibit these properties. However, most fungi have hydrolytic properties. 
During a mass die-off of bacteria, over a short period of time, under suitable conditions, non-hydrolyzed organic matter remains and does not perish without a trace. Modern knowledge argues that there is no matter on Earth which is not subjected to the effect of the hydrolytic and synthetic activity of microorganisms, but the depth and rate of change due to this effect are quite different. Nevertheless, even after microorganisms acquired the ability to hydrolyze dead organic polymers, and later on living ones as well ("pathogenesis"), all the same, synthetic processes have remained dominant and some, particularly heteropolymers (lignin, keratin, chitin, wax, and kerogens in particular) are still difficult to decompose. This results in the accumulation of organic matter and the formation of matter called "humus" (Семенов, Когут, 2015). In soil science, several thousand scientific papers and many books are published worldwide annually; however, this review article does not aim to survey this whole multitude of publications, but to summarize the current state of modern knowledge, primarily microbiological understanding, of the soil ecosystem (soil).

\subsection{Modern definition of soil}

Modern understanding and, hence, definition of soil must emphasize its biological origin and the biodynamic essence of the soil concept. Only with this interpretation can soil health as a soil characteristic be understandable and valid. A holistic approach is proposed one that addresses soil as a product of long-term assimilatory and dissimilatory activities of microorganisms and plants in the dominating mineral/organic matter. Modern SE (soil) is a natural organo-mineral product formed and maintained under local climate conditions, involving continuous microbe-plant interactions in the quantitatively dominating inorganic matter. The product contains living organisms (biota), their remains and metabolites, and biophilous elements. This product is the site of biological and physicochemical processes biochemical cycling of elements and cycling of microorganisms. It has substantial buffering properties with respect to stress; it supplies nutrients to plants and the living world in the soil; and is a source of biological diversity and a gathering place for living organisms. It is this very SE biological component that performs the function of environmental formation and maintenance. Therefore, it is normal i.e. sustainable for an autonomous SE to use, quite legitimately, biological and ecological characteristics such as soil health and, maybe, soil

pathology. Among the many characteristic abilities of the soil biological component, special emphasis should be placed on its self-reproducibility, self-supply and dynamism (Семенов, Семенова, 2018).

As already pointed out, the microbial community, as an active integral part of the soil, has the capacity to hydrolyze part of organic polymers into simple ingredients, on the one hand, and subject them to transformation into a form difficult to assimilate or to an inert form, on the other, leading to the formation and accumulation of the organic component of the SE. It is obvious that higher organisms can survive without microorganisms only for a short evolutionary time, whereas microorganisms, particularly prokaryotes, can survive indefinitely without higher organisms. In this way, the origin and formation of soil, the accumulation and maintenance are incessant, 
dynamic, but uneven, differently oriented biological processes without which the formation of the product called soil is impossible. This is confirmed by the existence of the parent material, but not of the soil, on neighboring planets, which are devoid of life (O’Neill et al., 1986; Barrios, 2007; Semenov, Semenova, 2018).

\section{Soil ecosystem (soil) health - a new property of the soil ecosystem}

The new category and characteristic of the soil ecosystem (SE) - soil health - has arisen among members of the scientific and social community in response to the change in both ecosphere composition and the quality of production, primarily plant production, and, indirectly, livestock production. The traditional characteristics of the soil such as soil quality and fertility were considered insufficient by the scientific community. The situation was particularly harsh at the time farmers converted to organic farming, when SE biological characteristics and evaluation parameters prevailed over traditional physicochemical categories. This resulted in the need to introduce a new category - soil health (Doran et al., 1996; Van Bruggen, Semenov, 2000; Đukić et al., 2011). Over a relatively short historical period, goals and tasks needed to solve this scientific and technical problem were defined, and methods for the primary parametric characterization of soil health (SH) were proposed (Семенов et al., 2011a, 2011b). Since there was no difference between the first definitions of $\mathrm{SH}$ and the definitions of soil quality, we proposed a comprehensive definition of soil health (Đukić et al., 2007; Đukić et al., 2011; Семенов et al., 2011b; Семенов, Соколов, 2016; Semenov, Semenova, 2018).

Accordingly, soil health is a biological category that reflects the dynamic state of the biotic component in the organo-mineral complex of the soil; this biological category is characterized by appropriate activities related to biological processes (synthesis and hydrolysis) in a particular naturally occurring climate zone, their ability to overcome disturbing impacts (biotic and abiotic stress agents), and a closed cycle of biophilous elements (self-sufficiency) and microorganisms. Another characteristic of a healthy soil in agrocenoses is that its quality is harmonized with standardized indicators and that its fertility is adequate (for the naturally occurring climate zone) (Семенов et al., 2011b; Semenov, Semenova, 2018). Such a definition of soil health, which is applicable to any soil (except abnormal ones), does not contradict the essence of traditional characteristics; rather, it integrates their essence, as indicators of the dynamics of the biotic component activity are correlated both with the physicochemical indicators of the soil and with the current level of soil fertility.

\subsection{Soil ecosystem health and methods for parameter determination}

To overcome difficulties in the elaboration of soil health determination methods, the concept of "disturbing influences" (DI) and the fluctuating dynamics of MP and MC development was helpful (Семенов et al., 2011a,b). After the fluctuating dynamics of the MC is obtained, a quantitative parameter is calculated. To this end, values for peak 
widths (periods) at their half-maximum (amplitude) in highest peaks are compared in control (healthy) soil vs. tested soil, after the addition of NV (glucose) (Семенов et al., 2011a,b; Semenov, Semenova, 2018; URL: http://bankpatentov.ru/node/62779). Importantly, this method and further ones must satisfy the four principles: (1) comparing the tested soil with the "healthy" (conditionally etalon or conventionally healthy) soil of one and the same genesis and from the same region; (2) using only fresh soil samples - principle of nativeness; (3) applying the same stress agent to all samples compared; (4) conducting dynamic observations and determinations.

As glucose is the stress agent used, this method is termed "the heterotrophic parameter of soil health" (Семенов et al, 2011; Семенов, Соколов, 2016). On a daily basis, over five days, the dynamics of the velocity (V) of CO" evolution from the soil is measured and parameters are calculated (Семенов et al., 2011b).

\section{Conclusion}

Microorganisms can be objectively classified into trophic groups based on physiological indicators such as: a) values for the substrate constants - Ks and/or Km; b) value of the energy consumed for maintenance - $\mathrm{m}$; c) existence and position of "narrow sites" in the microbial metabolism. The integrity to the trophic structure of the microbial community is continuously provided by the distinctive characteristics and the norms of reaction of community components, expressed in the concentrations and chemical complexity of substrates, on the one hand, and in the limits of variation in the physiological and biochemical constants, on the other. This is precisely why microbiologists are of the opinion that modern soil should be taken as a biological system. It is precisely the biological component that creates and enables the functions of this complex system; therefore, it is appropriate to use biological characteristics such as soil health and soil "pathology", soil immunity and soil therapy. The new characteristic of the SE - health - contains undoubtedly essential and substantial, but still systemically unintegrated characteristics such as soil quality and soil fertility. The theoretical elaboration and practical embodiment of the soil health concept have made important scientific progress in soil ecology today.

\section{References}

ГОСТ 27593-88. (2008): Почвы. Термины и определения.

Добровольская Т.Г. (2002): Структура бактериальных сообществ почв. М.: ИКЦ Академкнига. $282 \mathrm{c}$.

Добровольский Г.В. и др. (2011): Роль почвы в формировании и сохранении биологического разнообразия. Колл. авторов. М.: Товарищество научных изданий КМК. $273 \mathrm{c}$.

Заварзин Г.А. (1970): К понятию микрофлоры рассеяния в круговороте углерода // Журн. общ. биол. 31 (4): 386-393.

Заварзин Г.А., Бонч-Осмоловская Е.А. (1981): Синтрофные взаимодействия в сообществах микроорганизмов // Изв. АН СССР. Сер. биол. № 2. С. 165-173. 
Заварзин Г.А. (1989): Микробные сообщества в прошлом и настоящем. Микробиол. журнал. 51 (6): 3-14.

Заварзин Г.А. (1990а): Заповедники для микробов. Природа. № 2: 39-45.

Заварзин Г.А. (1990b): Корреляция филогенетической и экологической классификации прокариот. Журн. общ. биол. 51 (5): 590-599.

Заварзин Г.А., Герасименко Л.М., Жилина Т.Н. (1993): Цианобактериальные сообщества гиперсоленых лагун Сиваша. Микробиол. 62: 113-126.

Заварзин Г.А., Жилина Т.Н., Кевбрин В.В. (1999): Алкалифильное микробное сообщество и его функциональное разнообразие. Микробиол. 68 (5): 579-599.

Заварзин Г.А. (2004): Развитие микробных сообществ в истории Земли. Сб. к 70-ти летию института микробиологии им. С.Н. Виноградского. М.: Наука: 149-159.

Звягинцев Д.Г. (1987): Почва и микроорганизмы. М.: изд-во Моск. ун-та. 256 с.

Звягинцев Д.Г., Добровольская Т.Г., Бабьева И.П., Чернов И.М. )1999): Развитие представлений о структуре микробных сообществ почв. Почвоведение. № 1: 134-144.

Котелевцев С.В. (2019): Развитие идей В.И. Вернадского о роли живых организмов в биосфере. Экологическая химия, 28 (1): 57-58.

Ножевникова А.Н. (1987): Биотопливо и микроорганизмы / Сб. Биоценоз в природных и промышленных условиях. Пущино: 93-109.

Ножевникова А.Н. (1991): Рост и взаимодействие агаэробных бактерий в метаногенных фссоциациях и смешанных культурах. Сб. Итоги науки и техн. Микробиология. М.: ВИНИТИ. Т. 24: 116-148.

Семенов А.М. (2005): Трофическое группирование и динамика развития микробных сообществ в почве и ризосфере. Дисс. на соиск. уч. степ. докт. биол. наук. М.: МГУ. МАКС Пресс. 68 c.

Семенов А.М. (2010): Законы развития микробных популяций и их практическое использование / Мат-лы 7 Междунар. научн. нонф. «Современное состояние и перспективы развития микробиологии и биотехнологии». 31 мая -4 июня 2010 г. Минск. Беларусь: 71-74.

Семёнов А.М. (2011): Фундаментальные законы экологии в разработке способов определения здоровья почвы / Мат-лы Всерос. научн. конф. «Биосфера - почвы человечество: устойчивость и развитие». М., 14-16 марта 2011: 371-381.

Семенов В.М., Когут Б.М. (2015): Почвенное органическое вещество. М.: ГЕОС. 233 с.

Семенов А.М., Соколов М.С. (2016): Концепция здоровья почвы: фундаментальноприкладные аспекты обоснования критериев оценки. Агрохимия. № 1: 146-161.

Семенов А.М., Семенова Е.В. (2018): Почва как биологическая система и ее новая категория - здоровье. Успехи современной биологии. Т. 138. № 2: 115-125.

Семенов А.М., Ван Бругген А.Х.К., Бубнов И.А., Семенова Е.В. (2009): Система для количественного определения эмиссии газов из образцов почвы, компостов и других твердых субстратов. Патент на полезную модель. № 90212. РФ 27.12.2009.

Семенов А.М., Ван Бругген А.Х.К., Бубнов И.А., Семенова Е.В. (2011а): Способ определения параметра здоровья у образцов почвы, компостов и других твердых субстратов. Патент № 2408885 РФ 10.01.2011.

Семенов А.М., Семенов В.М., Ван Бругген А.Х.К. (2011б): Диагностика здоровья и качества почвы. Агрохимия. № 12: 4-20.

Стейниер Р., Эдельберг Э., Ингрэм Дж. (1979): Мир микробов. В трех томах. М.: Мир.

Турчин П.В. (2002): Есть ли общие законы в популяционной экологии. Журн. общ. биол. 63 (1): 3-14. 
Barrios E. 2007. Soil biota, ecosystem services and land productivity. Ecol. econom. 64: 269285.

Doran J.W., Sarrantonio M., Liebig M.A. (1996): Soil health and sustainability. Advanc. agron. 56: $1-54$.

Đukić D. Jemcev V.T., Mandić L. (2011): Sanitarna mikrobiologija zemljišta, Agronomski fakultet u Čačku, 502 str.

Đukić D., Jemcev V.T Kuzmanova J. (2007): Biotehnologija zemljišta. Budućnost, Novi Sad, 529 str.

Fry J.C. (1990): Oligotrophs. Microbiology of extreme conditions. Ed. C. Edwards. Open Univ. press. Stony Stratford, UK: 93-116.

Hofman-Bang J., Zhrng D., Westermann P. et al. (2003): Molecular ecology of anaerobic reactor system / Biomethanation I, Advances in biochemical engineering. Biotechnology. Ed. B.K. Ahring. Germ.: Springer-Verlag. 81: 151-203.

Hug L. (2018): Sizing up the uncultured microbial majority. mSystems. 3. № 5. e00185-18.

Kirk J.L., Beaudette L.A., Hart M. et al. (2004): Methods of studying soil microbial diversity. J. microb. methods. 58: 169-188.

O’Neill R.V., De Angeles D.L., Waide J.B., Allen T.F.H. (1986): A hierarchical concept of ecosystems, Princeton. NJ: Princeton Univ. press. 263 p.

Poindexter J.S. (1981): Oligotrophy. Feast and famine existence // Adv. microbiol. Ecol. 5: 6389.

Semenov A.M. (1991): Physiological bases of oligotrophy of microorganisms and concept of microbial community. Microb. ecol. 22: 239-247.

Semenov A.M., Kuprianov A.A., Van Bruggen A.H.C. (2010): Transfer of enteric pathogenes to successive habitats as part of microbial cycles. Microb. ecol. 60 (1): 233-249.

Semenov A.M., Semenova E.V. (2018): Soil as a Biological System and Its New Category Health. Biol. bull. rev. 8 (6): 463-471.

Van Bruggen A.H.C., Semenov A.M. et al. (2006): Relation between soil health, wave-like fluctuations in microbial populations, and soil-borne plant disease management. Europ. j. plant path. 115: 105-122.

Van Bruggen A.H.C., Semenov A.M. (2000): In search of biological indicators for soil health and disease suppressions. Appl. soil ecol. 15 (1): 13-24.

Zumstein E., Moletta R., Godon J.J. (2000): Examination of two years of community dynamics in an anaerobic bioreactor using fluorescence polymerase chain reaction (PCR) singlestand conformation polymorphism analysis. Environm. microbiol. 2: 69-78. 


\section{MIKROORGANIZMI ZEMLJIŠNOG EKOSISTEMA I NJEGOVO ZDRAVLJE}

\section{Semenov Aleksander Mihailovič ${ }^{1}$, Đukić Dragutin ${ }^{2}$, Mandić Leka $^{2}$}

${ }^{1}$ Biološki fakultet, Katedra za Mikrobiologiju, M. V. Lomonosov Moskovski državni Univerzitet, Leninskie gori, 1/12,119234, Moskva, Ruska federacija

${ }^{2}$ Agronomski fakultet u Čačku, Katedra za mikrobiologiju i mikrobiološku biotehnologiju, Univerzitet u Kragujevcu, Cara Dušana 34, 3200 Čačak, Srbija

\section{Rezime}

U radu se razmatraju savremene (na kraju prve četvrtine 21. veka) predstave o mikrobnoj zajednici (MZ), strukturi i konceptima koje znače napredak u pogledu spoznavanja MZ. Razmatraju se mišljenja sa aspekta savremenih saznanja o ulozi i funkcijama mikrobnih zajednica u postanku i održanju proizvoda, koji se tradicionalno naziva zemljište, ali koji je, u suštini, proizvod integracije različitih bioloških zajednica i supstanci, proizvod koji je beskrajno višeznačan i pojmovno različit i predstavlja, sam po sebi, zemljišni ekosistem (ZE). Obrazlaže se potreba razvoja nove koncepcije za upoznavanje tog proizvoda - zdravlje zemljišta (ZZ), kao integracije savremenih znanja o MZ i njihovim funkcijama. Ukratko se navode i metode određivanja parametara zdravlja zemljišta.

Ključne reči: mikrobna zajednica, zemljište, zemljišni ekosistem, zdravlje zemljišta. 